\title{
SZÉLTURBINA TELEPÍTÉSÉHEZ TETŐ DŐLÉSSZÖGÉNEK VIZSGÁLATA
}

\section{ROOF PITCH ANGLE EXAMINATION FOR WIND TURBINE INSTALLATION}

\author{
Hetyei Csaba, ${ }^{1}$ Szlivka Ferenc ${ }^{2}$ \\ ${ }^{1}$ Óbudai Egyetem, Biztonságtudományi Doktori Iskola, Budapest, Magyarország, \\ hetyei.csaba@phd.uni-obuda.hu \\ ${ }^{2}$ Óbudai Egyetem, Bánki Donát Gépész és Biztonságtechnikai Mérnöki Kar, Budapest, Magyarország
}

\begin{abstract}
Due the nowadays increasing energy demand, the renewable energy sources and they utilization come into view. Thanks to the Smart Grid, which is currently developing, and with the help of the evolving technologies, we are trying to extract more and more energy from places that have not been or could not be economically viable. In our article, we examine the flow field for a fictional warehouse building, depending on the roof pitch angle. The purpose of the analysis was to select the optimal angle where a roof mounted horizontal axis wind turbine (HAWT) could perform well.
\end{abstract}

Keywords: $C F D, B A W T, H A W T$, simulation.

\section{Összefoglalás}

Napjainkban jelentkező egyre nagyobb energiaigény miatt, előtérbe kerülnek a megújuló energiaforrások és különféle hasznosítási módjaik. A jelenleg kialakulóban lévő okos hálózat (Smart Grid), és a fejlődő technika segítségével egyre több olyan helyről is energiát próbálunk kinyerni, melyekből eddig nem lehetet, vagy gazdaságilag nem volt célszerü. Cikkünkben egy képzeletbeli raktárépület környezetében kialakuló áramlási képet vizsgálunk meg, a tető dőlésszögének függvényében. A vizsgálat céljául tűztük ki, hogy kiválasszunk egy dőlésszöget, mellyel a tetőre szerelt kisteljesítményű vízszintes tengelyű szélturbina optimálisan működhet.

Kulcsszavak: CFD, BAWT, vízszintes tengelyü szélturbina, szimuláció.

\section{Bevezetés}

Napjainkban jelentkező egyre nagyobb energiaigény miatt, előtérbe kerülnek a decentralizált okos hálózatba integrálható lehetőségek. Ilyenek a biomasszát, geotermikus-, nap-, víz- és a szélenergiát hasznosító eszközök.

A megújuló energiaforrások piacát nézve, évről évre növekvő trend figyelhető meg. Egy UNEP-es tanulmány szerint 2017-ben az új megújuló erőforrásokra összesen 280,2 milliárd USD-t fordítottak, melyből 161 milliárdot napenergiára, 107 milliárdot szélenergiára [1].
Cikkünkben a szélenergia hasznosításával, azon belül is az épített környezetbe telepíthető kis teljesítményű szélturbinákkal foglalkozunk. Témaválasztásunkat az indokolja, hogy a jelenleg elérhető szakirodalom nem, vagy csak nehezen reprodukálható, így bemeneti feltételnek a későbbi kutatásainkhoz nem tudtuk felhasználni őket. Például Y. Ozmen és szerzőtársai [2] egy nyeregtetőt vizsgáltak néhány nevezetes dőlésszöggel. I. Abohela és szerzőtársai [3] és L. Ledo és szerzőtársai [4] egy beépített kisvárosi környezetben pár tetőszerkezetet és azok különböző konfigurációit vizsgálták az épületek és a szél irányának függvényében. 


\section{Szélenergia hasznosítása urbanizált környezetben}

Az urbanizált régióba - a méretük miatt - a kisteljesítményü szélturbinák telepíthetők. Ezeket a turbinákat az IEC 64100-2-es szabvány úgy definiálja, hogy a lapátok által súrolt területnek $200 \mathrm{~m}^{2}$-nél kisebbnek és az előállított feszültségnek egyenáram esetén $1000 \mathrm{~V}$, váltóáram esetén 1500 V-nál kevesebbnek kell lennie [5].

Világviszonylatban ezeknek a turbináknak a részesedése csekély, 2015-ben a 948,9 MW telepített teljesítmény a világ telepített szélturbina teljesítményének a 0,22\%-át jelentette.

Előrejelzések szerint 2020-ra 1,9 GW telepített kisteljesítményű szélerőmű lesz világszerte [5]. Százalékos megoszlását tekintve jelenleg elhanyagolhatónak tűnik ezeknek a szélturbináknak az energiapiacon mutatott részesedése, de a jövőben kialakulóban lévő okos energiahálózatnak (smart grid), valamint az energiahálózattól távoli területek energiaigényének a kiszolgálásában fontos szerepet foglalhatnak el.

A szakirodalom [6] szerint a szélturbinával kibővített épületeknek (BAWT - Building Augmented Wind Turbines) három típusa létezik:

- a szélturbinával felszerelt,

- két épület közé telepített,

- az épületbe telepített szélturbina.

A későbbiekben az első esettel foglalkozunk. A második esetre a bahreini Világkereskedelmi Központ, a harmadikra a guangzhoui Pearl River torony lehet példa.

Mind három eset azt használja ki, hogy az épületek közelében lecsökken a szél számára rendelkezésre álló hely, így az épületet kikerülve, vagy a számára kialakított szélcsatornában tud tovább haladni. Mivel a szél a szabadáramláshoz viszonyítva kisebb térrészen át tud folyni, így a kontinuitás törvény értelmében a sebessége felgyorsul, így az áramlásba helyezett turbina több kinetikus energiát tud hasznosítani, mint ha a szabadáramlásba lenne telepítve.

\section{Véges térfogat módszerre alapú szi- mulációkról}

A numerikus áramlástani szimulációs szoftverek közül a SOLIDWORKS Flow Simulationt választottuk, ami egy véges térfogat módszerre (VTM) épülő hő- és áramlástani szimulációs szoftver a SOLIDWORKS CAD rendszerébe integrálva.

A VTM alapú szimulációs szoftver a rendelkezésre álló teret véges térfogatú cellákra bontja, és az így kapott térrészekre a megmaradási tételek segítségével kiszámolja a nyomás, a sebesség és a hőmérséklet mezőket. Ez jellemzően a következő transzport egyenletre épül:

$$
\frac{\partial}{\partial t} \int_{V} U d V+\oint_{A} \underline{F} d \underline{A}-\int_{V} S_{V} d V+\oint_{A} \underline{S}_{A} d \underline{A}=0
$$

Az egyenletben $\partial / \partial t$, az időfüggő tag (állandósult esetben értéke 0 ), U, egy maradó mennyiség térfogati sűrüsége, $F$, az adott jellemző fluxusa, $S_{V}$ és $S_{A}$ a térfogati és a felületi forrás az adott $F$ fluxusra.

A szimulációs szoftver a tér diszkretizált részeire elvégzi a számításokat addig iterálva, míg a szimuláció el nem éri a leállítási kritériumot. Jellemzően ez a leállítási kritérium az egyenlet jobb oldalán lévő 0 érték közelítése, egy elhanyagolható nagyságú hibával.

\section{Vizsgált eset}

Szimulációinkhoz egy raktárház tetőszerkezetét választottuk. A vizsgált geometria a 1. ábrán látható.

A szimuláció során sík áramlást feltételeztünk, így a vizsgált geometria egy olyan részét szimuláltuk, ahol hossz mentén ugyanolyan áramlási kép alakul ki, mint a többi keresztmetszetben. Ebből adódik, hogy az épület hossza figyelmen kívül hagyható. Az így kapott 2D-s geometria szélessége $20 \mathrm{~m}$, magasság a tető dőlésszögének függvényében változott 5,375 m és 10,275 m között. A vizsgált tetődőlésszög $5^{\circ}, 10^{\circ}, 15^{\circ}, 20^{\circ}, 25^{\circ}$ és $30^{\circ}$.

$\mathrm{Az}$ így előállított geometriákból azt az esetet kerestük, ahol az épület tetején a gerinc felett a lehető legnagyobb a szélsebesség, ugyanis ebben az esetben áll a szélkerekek rendelkezésére a legtöbb kinetikus energia, amit hasznosítani tudnak. Ennek méréséhez létrehoztunk a szélturbinának egy vizsgálati térfogatot, mely a tető gerincétől $1 \mathrm{~m}$ magasan helyezkedett el, és $0,4 \mathrm{~m} \times 2 \mathrm{~m}$ volt a síkbeli kiterjedése.

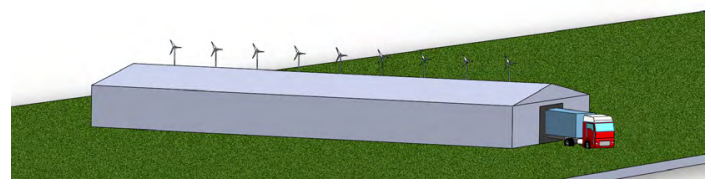

1. ábra. Vizsgált épület és környezete

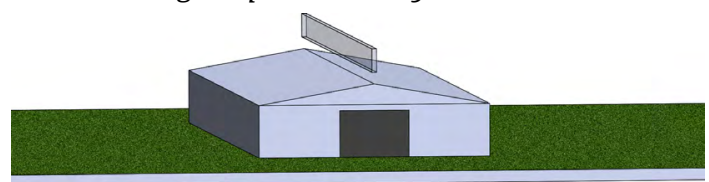

2. ábra. Vizsgálati térfogat a tetőszerkezet felett 


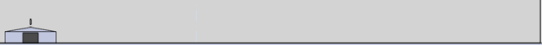

3. ábra. Áramlási tér

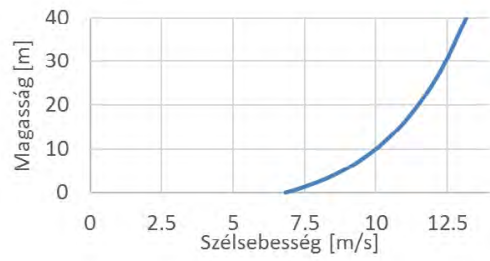

4. ábra. $10 \mathrm{~m} / \mathrm{s}$ szél esetén a szélsebesség profilja 0 és 40 méter magasság között

\subsection{Peremfeltételek}

A vizsgált áramlási tér egy $270 \times 40$ m téglalap volt, melyben az épület elhelyezkedése a következő képen látható.

Az áramlási térbe belépő szélsebesség $10 \mathrm{~m}$ magasságban $10 \mathrm{~m} / \mathrm{s}$, a többi magasságban a WMO (World Meteorological Organization - Meteorológiai Világszervezet) által javasolt összefüggés szerint [7] lépett be. Az így kialakuló sebességprofil a következő képlettel számítható, és értéke az általunk vizsgált esetben a következő ábrán látható.

$$
\mathrm{v}_{\mathrm{h}}=\mathrm{v}_{10} \cdot(0,233+0,656 \cdot \lg (\mathrm{h}+4,75))
$$

Az egyenletben, $v_{h}$, a vizsgált magasságban a szél becsült sebessége, $\mathrm{v}_{10}$, a 10 méter magasságban mért szélsebeség, $h$, a vizsgált magasság.

Az áramlási térben a turbulencia leírásához k- $\varepsilon$ modellt használtunk.

$\mathrm{Az}$ áramlási térben minden felületet ideálisnak tekintettünk, így sem felületi érdességgel, sem felületi egyenetlenséggel nem rendelkeztek. Ezen felül, az áramlási térben az áramlást semmilyen épített és élő környezeti elem nem befolyásolta.

\subsection{Hálózás}

A véges térfogat módszer az áramlási teret a nevében is szereplő módon, véges térfogatú elemekre bontja. Az általunk választott szoftver blokkstrukturált hálózást hoz létre, mely az áramlási tér felbontására csak téglatest elemeket használ.
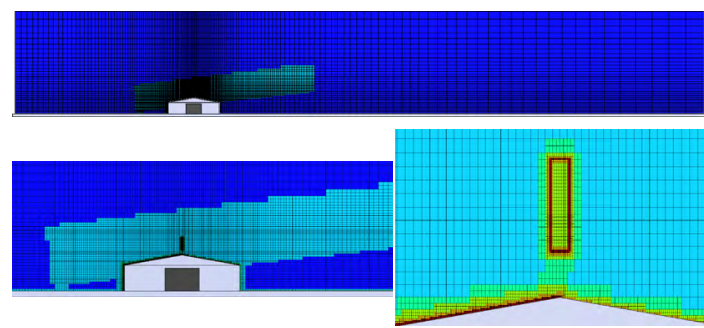

5. ábra. VT háló a $10^{\circ}$-os dőlésszög esetén
A vizsgált esetekben a hálózás elemszáma a tető dőlésszögétől függően változott, 231412 és 239276 darab között.

A 5. ábrán a hálózás $10^{\circ}$-os dőlésszög mellett a látható. Kék színnel azok a cellák vannak jelölve, melyek nem lettek sürítve, a piros felé haladva a sűrítések száma egyre nő (a piros cellák ötször lettek sürítve, a sötétkékek egyszer sem).

\subsubsection{Hálófüggetlenségi vizsgálat}

Az eredmények megbízhatóságának érdekében a véges térfogat hálónkat a $10^{\circ}$ dőlésszög esetén hálófüggetlenségi vizsgálatnak vetettük alá, melynek az eredményei a 6. ábrán láthatók.

\subsection{Szimuláció tulajdonságai}

A szimulációkat állandósult állapotban futtattuk 200 iterációig, majd időfüggő szimulációként folytattuk. A tranziens szimulációnak két leállítási feltételt adtunk, vagy 40 másodperc vagy 15000 iteráció után le kellett állnia. Ezek a feltételek közül minden esetben a 15000 iteráció teljesült előbb, a tető dőlésszögétől függően 31 és 35 másodperc között. A szimuláció futása közben az időlépést automatikusra állítottuk, így az 0,000987 és 0,003097 másodperc között változott. Az összes esetet minden időlépését vizsgálva az átlagos időlépés értéke 0,0020975 másodperc volt.

A szimuláció alatt megfigyelt értéknek állítottuk be a vizsgálati régió átlagos sebességét. Szimulációk végeztével megállapítottuk, hogy az átlagos szélsebesség egy adott érték körül ingadozik a turbulencia miatt. Összehasonlításhoz nem a teljes idősorokat használtuk, csak a megfigyelt érték utolsó egy másodpercének az átlagát.

\subsection{Vizsgált esetek eredményei}

Szimulációinkat lefuttatva eltérő átlagos sebességértékeket és áramlási képeket kaptunk, melyekből a $15^{\circ}$-os tetődőlésszöghöz tartozó a 7 . - 8. ábrákon látható.

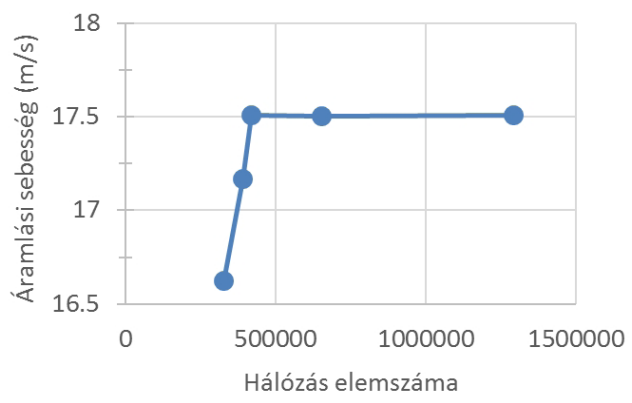

6. ábra. Vizsgált régió átlagos szélsebességének változása a hálózás függvényében 


\subsection{Eredmények kiértékelése}

Kapott eredményeinket többféle függvényillesztési módszerrel vizsgáltuk, ezek a 9. ábrán láthatóak.

A függvényillesztések közül a harmadfokú spline függvényt választottuk, mely a következő ábrán látható. (A kiinduló- és a végpontra történő pontosabb függvényillesztés miatt még $0^{\circ}$ és $35^{\circ}$-os dőlésszögre is lefuttattuk szimulációinkat.)

A 10. ábra alapján a legnagyobb átlagos szélsebesség 18,9486 m/s, ami 14,2208ºs dőlésszögnél ébred.

\section{Következtetések}

Az előzetesen ismertetett esetekben egy nyeregtetős építményt vizsgáltunk síkáramlást feltételezve.

Vizsgálatunk tárgya a szélsebesség növelése volt, tető dőlésszögének változtatásával. Az így kapott eredményekre többféle függvényt illesztettünk, melyek közül a harmadfokú splinet választottuk. A függvényről leolvasva megállapítottuk, hogy a tető gerince közelébe elhelyezett vizsgálati térfogatban, a legnagyobb átlagos szélsebesség $14,22^{\circ}$-os dőlésszögnél ébredt.

Későbbiekben 2,5D-s és 3D-s szimulációkkal öszsze tudjuk hasonlítani a mostani eredményein-
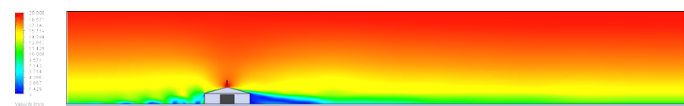

7. ábra. $15^{\circ}$-os dőlésszög esetén az áramlási kép az áramlási térben

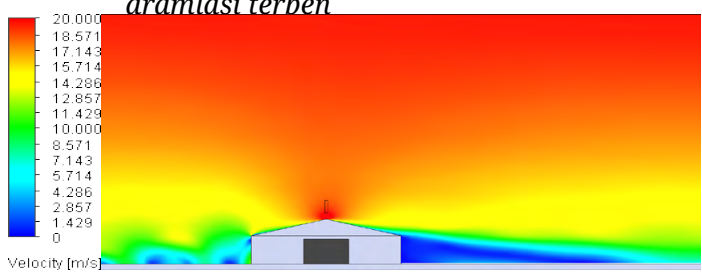

8. ábra. $15^{\circ}$-os dőlésszög esetén az áramlási kép az épület környezetében

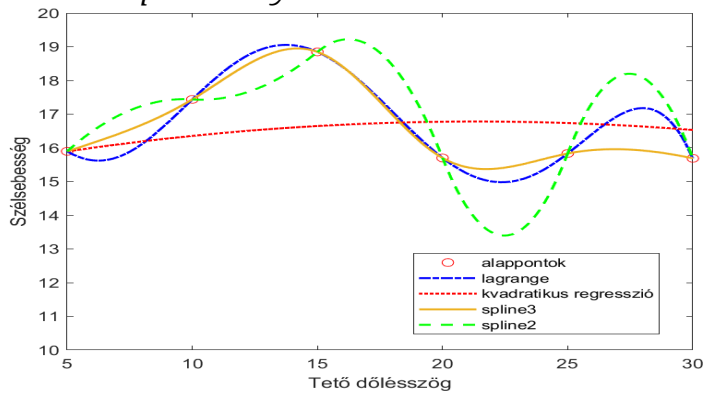

9. ábra. Vizsgálati térfogatban ébredő átlagos sebességek a tető dőlésszögének függvényében (különböző függvényillesztésekkel)

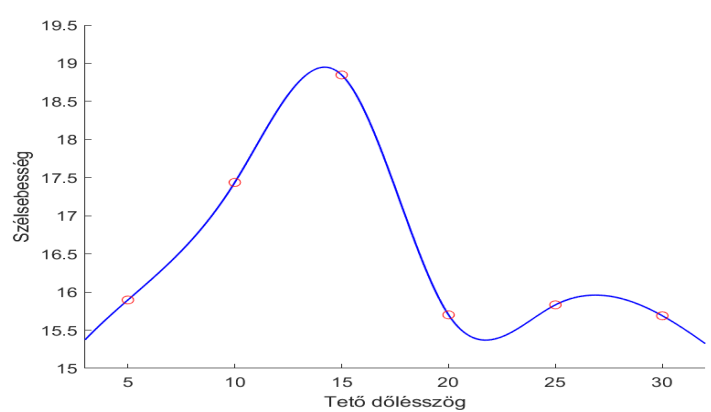

10. ábra. Vizsgálati térfogatban ébredő átlagos szélsebességek változása a tető dőlésszögének függvényében

ket. 3D-s áramlástani esetben lehetőségünk lesz a szélturbina modellezésére is, így annak a teljesítményét is vizsgálni tudjuk.

Vizsgálatunk folyatásával célunk a nyeregtetőhöz egy olyan dőlésszög, esetleg előterelő kiválasztása lesz, mellyel egy adott szélturbinageometria a lehető legoptimálisabban tud üzemelni, ezáltal a közeljövőben kialakuló okos hálózatoknak (smart grid) fontos része lehet.

\section{Köszönetnyilvánítás}

Az Emberi Erőforrások Minisztériuma ÚNKP-18-3-IOE-87 kódszámú új nemzeti kiválóság programjának támogatásával készült.

\section{Szakirodalmi hivatkozások}

[1] Frankfurt School - UNEP Collaborating Centre for Climate \& Sustainable Energy Finance: Global trends in renewable energy investment 2018 p. 15. https://europa.eu/capacity4dev/file/71900/download?token=57xpTJ4W

[2] Ozmen Y., Baydar E., van Beeck J. P. A. J.: Wind flow over the low-rise building models with gabled roofs having different pitch angles. Building and Environment, 95. (2016) 63-74. https://doi.org/10.1016/j.buildenv.2015.09.014

[3] Islam Abohela, Neveen Hamza, Dudek S.: Effect of roof shape, wind direction, building height and urban configuration on the energy yield and positioning of roof mounted wind turbines. Renewable Energy, 50. (2013) 1106-1118.

https://doi.org/10.1016/j.renene.2012.08.068

[4] Ledo L., Kosasih P. B., Cooper P.: Roof mounting site analysis for micro-wind turbines, Renewable Energy, 36. (2011) 1379-1391.

https://doi.org/10.1016/j.renene.2010.10.030

[5] World Wind Energy Association: 2017 Small Wind World Report. WWEA Head Office, Bonn 2017.

https://www.wwindea.org/wp-content/uploads/ filebase/small_wind」SWWR2017-SUMMARY.pdf

[6] Casini M.: Small Vertical Axis Wind Turbines for Energy Efficiency of Buildings. Journal of Clean Energy Technologies, 4/1. (2016) 56-65.

[7] Tóth Gábor: Energia célú szélmérés. Gödöllő, 2005. 